\title{
The Isolation DNA Chromosome of Aeromonas Hydrophila Bacteria Isolate Local East Java
}

\section{Retno Sri Wahjuni ${ }^{1}$ and Gandul Atik Yuliani²}

${ }^{1}$ Department of Health, Faculty of Vocational, Universitas Airlangga

${ }^{2}$ Department of Basic Veterinary Medicine, Faculty of Veterinary Medicine, Universitas Airlangga

\section{Abstract}

Aeromonasis Disease or the Ulcer Diseases caused by Aeromonas hydrophila often attacks fish and shrimps in ponds or aquariums. Aeromonasis shows clinical symptom of petechiae in scale and causes death. Aeromonosis can cause economic loss if not treated with medication accompanied with improved sanitation. This disease affects many freshwater fish farms in East Java. In a previous study, the authors had managed to characterize the antigenic protein derived from the OMP (outer

Corresponding Author: Retno Sri Wahjuni wahjuniretno@yahoo.com

Received: 8 June 2018 Accepted: 17 July 2018 Published: 8 August 2018

Publishing services provided by Knowledge $\mathrm{E}$

(c) Retno Sri Wahjuni and Gandul Atik Yuliani. This article is distributed under the terms of the Creative Commons

Attribution License, which permits unrestricted use and redistribution provided that the original author and source are credited.

Selection and Peer-review under the responsibility of the $2 n d$ ICVHE Conference Committee. membrane protein) Aeromonas hydrophila, therefore, it is necessary to perform sequencing protein-coding DNA. To achieve that goal, some of the explorative research laboratory methods performed are: Isolation of DNA fragments Aeromonas hydrophila through four stages, cell cultivation and harvesting of bacterial cells, cell Iysis, DNA purification and concentration chromosomal DNA. The results will be used as a predictive immunogenic determinant by the method Kolaskar and Tongaonkar.

Keywords: Aeromonas hydrophila, chromosomal DNA, immunogenic determinant

\section{Background}

Aeromoniasis has been recognized as an important pathogenic agent in freshwater fish farm for more than a decade. Especially the infection of Aeromonas hydrophila and $A$. sobria, they have caused a lot of loss in fish cultivation. The illness which is caused by this organism can be manifested in many ways such as hemorrhagic septicemia, basal ulceration, symptom septicemia, exophthalmoses and any others.

The disease control through antibiotic is not always successful and it can be harmful to the environment because the resistant bacteria can be selected and resistance can be transferred to fish or even human pathogens and other harmful bacteria. Therefore, it is essential to develop a vaccine to protect the fish against bacteria. However, high antigenic diversity among isolates of $A$. hydrophila is the major problem. Some of virulence factors may contribute the whole virulence of these bacteria. Including 
ekstraseluler Produk (ECP), S-layer and adhesin. The structure of $A$. hydrophila bacteria is unique unlike other gram negative bacteria. Those bacteria have villi and flagella in the outer surface of its body, consist of two components that have been identified as potential virulence factors, they are outer membrane protein (OMP) and lipopolysaccharide (LPS).

OMP bacteria Gram negative is a potential antigen which can directly induce specific hormonal immune responses that is limfosit $\beta$ cell lymphocytes, resulting the quick trigger formation of antibody. This protein has a role to show immunogenic characteristic in a particular molecule weight (Jawetz et al., 2004).

The A. hydrophila local isolate East Java has different nature and character with the isolate in other countries. Environmental influences such as climates, weather and temperature can cause some differences or change of every strain of bacteria. The aim of this research is to find and characterize of the protein-coding genes A. hydrophilo local isolate. The sequence of protein coding gene $A$. hydrophila local isolate which is obtain homology with the strain from other country (GenBank). Knowing homology and the differences of nucleotide place will affect the nature of its immunogenic and this information can be used to create the ingredients of sub unit vaccine. For the aforementioned objectives, the first step of biological molecular checkup is through isolation of chromosomal DNA.

Based on the aforementioned research background, it can be formulated with the following problems: how does the DNA result of degradation protein of Aeromonas hydrophila bacteria isolate local east Java and how much does the DNA protein content ofAeromonas hydrophila isolate local East Java?

\section{Research Method}

\subsection{The cultivation cells and the harvest of Aeromonas hydrophila bacteria cells}

The local A. hydrophila isolate collection came from several pound or freshwater pond in the east Java, they came from the golden fish pound or freshwater pond in Batu region, Gurami pound or freshwater pond in Tulungagung and Tilapia fish pond or freshwater pond in Sidoarjo. The sample of the research was the suspected fish which is infected by 'Ulcer disease' or 'Red Sore Disease', and another infected fish was taken to microbiology Laboratory Of Faculty Of Veterinary Universitas Airlangga Surabaya, 
to make a diagnosis and cultured with a special media of TSA and it was done by biochemical test.

\subsection{The lysis cell of Aeromonas hydrophila bacteria}

Cell degradation was done by sonication. A. hydrophila washed with PBS with centrifugation with $8.000 \mathrm{rpm}$ speed during 15 minutes. Aeromonas hydrophila Pellet was dissolved with $1 \mathrm{ml}$ of PBS then sonicated at $20 \mathrm{HZ}$ for $4 \times 4$ minutes with the interval time 2 minutes. Centrifuged supernatant was taken and returned at 8000 rpm for 15 minutes. The outcome of supernatant then stored for analysis of protein material. To prevent the protein damaged it is necessary to add protease inhibitors.

\subsection{The purification of chromosomal DNA}

The A. hydrophila sample was processed become a suspension by dissolving into PBS (Phosphate Buffer Saline). Put the A. hydrophila suspension into Eppendorf tubes by using a micropipette then add the Danazol $1000 \mu$ solution. After being mixed well it was incubated at the temperature room for about 2-15 minutes. The suspension mixture was centrifuged for 10 minutes at $4^{0} \mathrm{C}$ temperature at 10,000 rpm speed. Furthermore, the supernatant was taken 500 l and transferred into Eppendorf tube and added by 50oul absolute ethanol. The DNA will seem to hover and centrifuge for 10 minutes at $4^{0} \mathrm{C}$ temperature at $10,000 \mathrm{rpm}$ speed, it would precipitate the DNA. The last step was washing the DNA by adding $1000 \mu$ l ethanol $75 \%$ and disentrifuge about 10 minutes in $4{ }^{0} \mathrm{C}$ temperature with 10.000 rpm speed. The DNA can be dried to remove all the supernatant carefully and let the tube open for 5 minutes. Then the DNA was dissolved with $\mathrm{NaOH}\left(\mathrm{pH} 7.5\right.$ ) for about $50 \mu$ l dan keep in $4^{0} \mathrm{C}$ temperature [16].

\subsection{Determination of DNA concentration}

It is done by spectrophotometer UV in the wavelength $260 \mathrm{~nm}$, where the absorbance value is 1.0 is equivalent $50 \mu$ g of double-stranded DNA/ml. the purity of DNA can also be determined by the ratio. If the purity of ratio less than 1.8 it means that the DNA is not pure enough. 


\section{Result and Discussion}

\subsection{The cultivation cells and the harvest of Aeromonas hydrophila bacteria cell}

The research sample is Aeromonas hydrophila bacteria isolate local East Java isolate which was infected by Aeromoniasis in Sidoarjo Blitar and Malang region. The sample fish is the biggest commodity in those region, such as Gourami, catfish and goldfish.

In this research Aeromonas hydrophila local isolates is propagated on media stocks (Image 1) by culturing on Tryptic Soy solid media and incubated for 18-24 hours (Image 2).

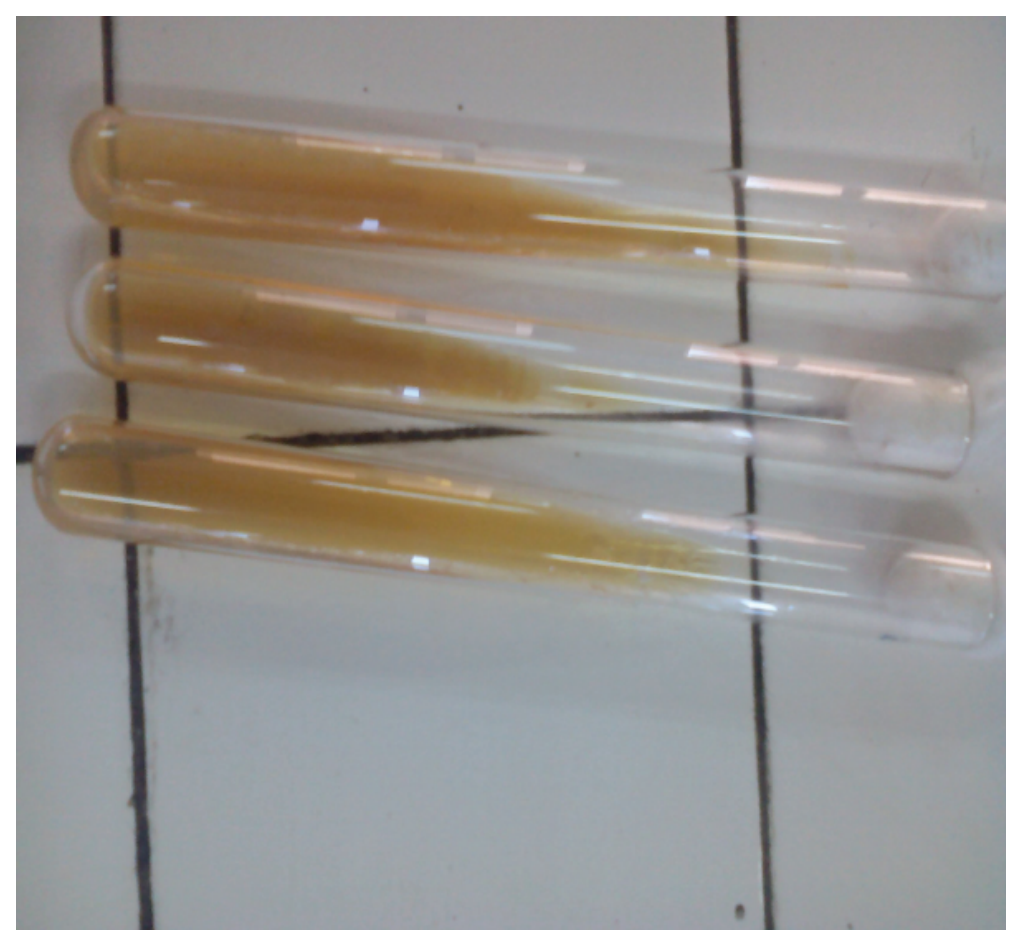

Figure 1: Isolate A. hydrophila in stock media.

\subsection{The lysis cell of Aeromonas hydrophila bacteria}

The bacterial degradation cells were done by sonication technique. A. Hydrophila from solid media can be washed by using PBS and centrifuge with 8.000 rpm speed for 15 minutes (Image 3). Furthermore, A. hydrophila pellet can be dissolved with $1 \mathrm{ml}$ of PBS and sonicated in $20 \mathrm{~Hz}$ for $4 \mathrm{x} 4$ minutes with the interval time for 2 minutes (Image 4 ) 


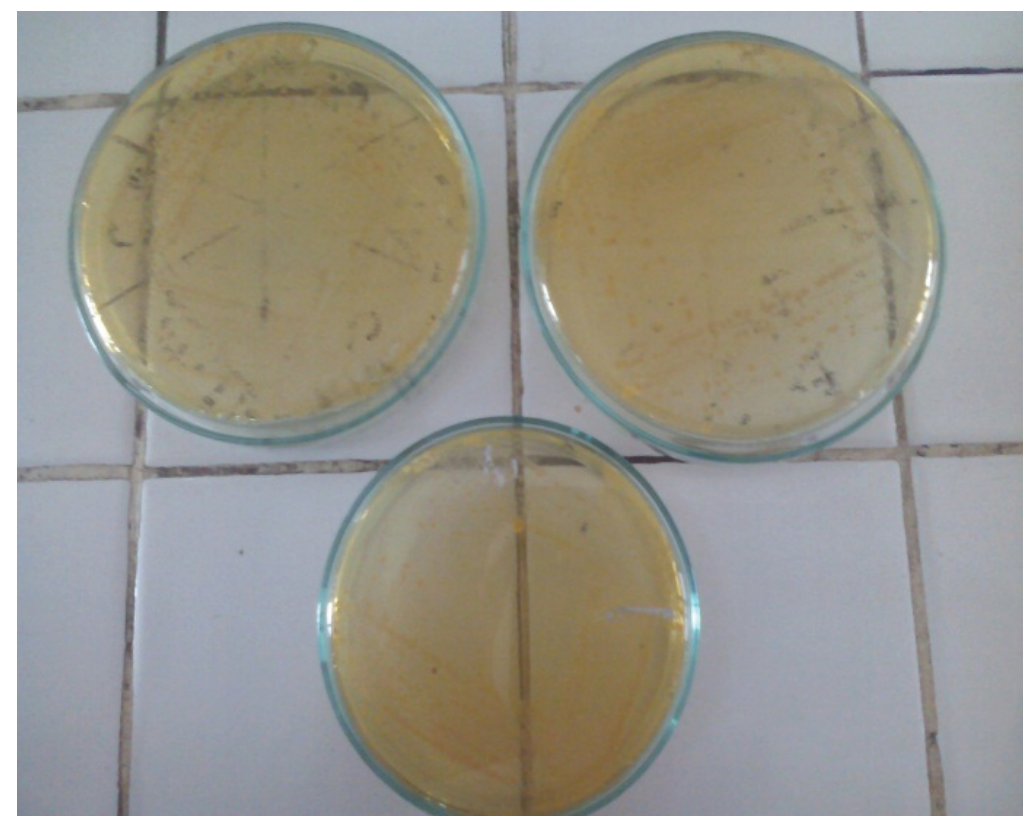

Figure 2: A. hydrophila isolate in TSA media

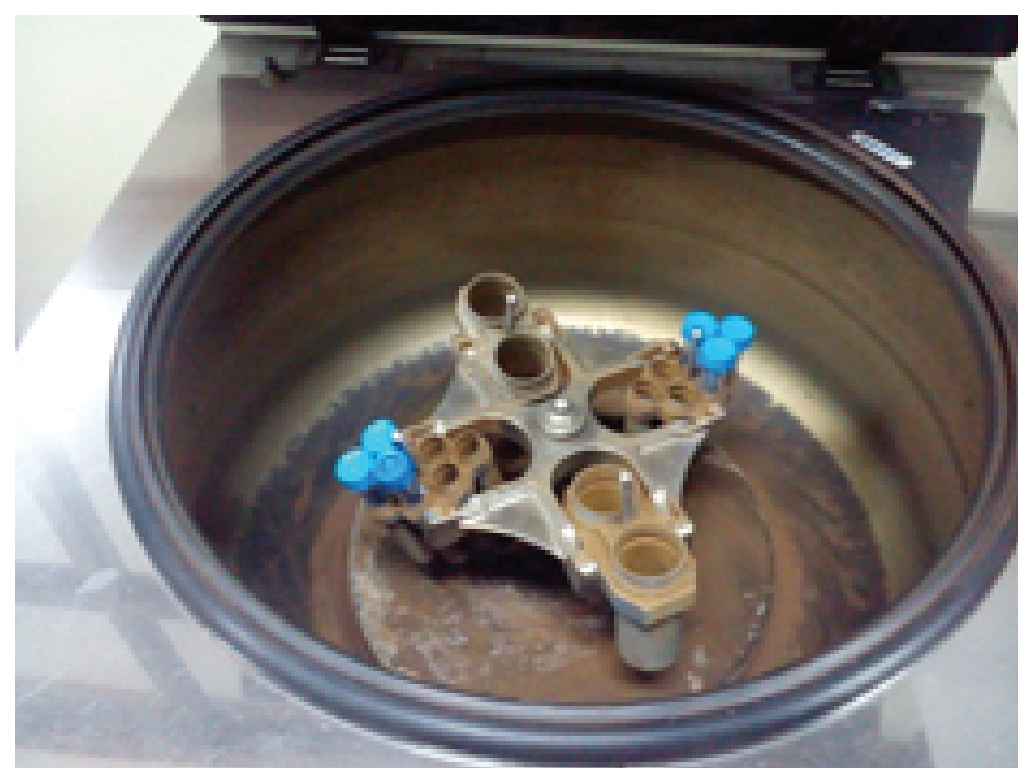

Figure 3: Isolates laundering A. hydrophila by centrifugation..

\subsection{The purification of chromosomal DNA}

After breaking of the bacterial cell walls after that purified the DNA, to separate DNA molecules of RNA and protein contaminants as well as from debris cell. The standard method that used for identification, separation and purification of DNA fragment by using lektroforesis agarosa gel. The DNA electrophoresis migration through agarose 


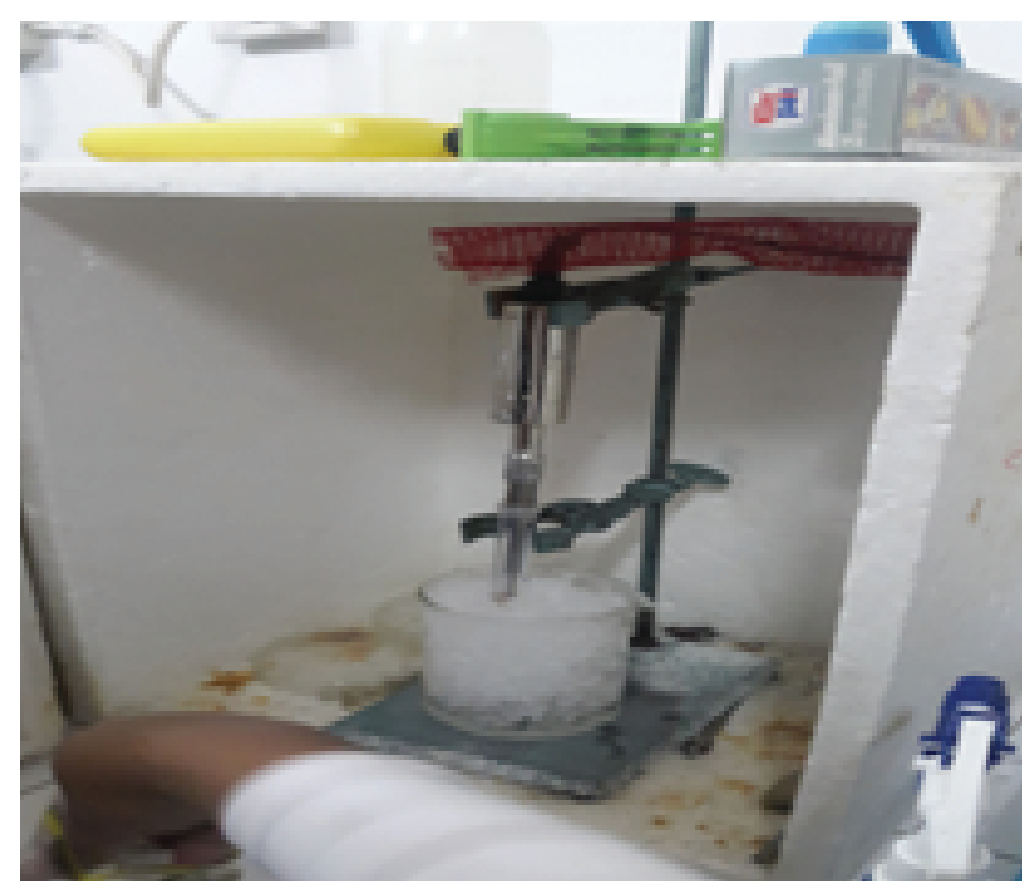

Figure 4: The degradation of cell walls of $A$. hydrophila by sonication.

gel was influenced by the size and conformation of the DNA molecule, the concentration of agarose, the electric current and temperature. The results of agarose gel electrophoresis of DNA chromosomes Aeromonas hydrophila can be seen in Image 5 .

The DNA result of degradation protein of Aeromonas hydrophila isolate local East was $400 \mathrm{bp}$. Then the DNA will be assessed its purity and quantified by using UV spectrophotometer.

\subsection{Determination of DNA concentration}

Quantitative DNA test by using UV-Vis spectrophotometer which has Nanotechnology, the pure DNA can absorbs the Ultraviolet light for their purine and pyrimidine bases. Double-stranded DNA can absorb UV light at $260 \mathrm{~nm}$. In this research, DNA concentration which was obtained was 51.4 nanograms/microliter.

\section{Conclusions and Suggestions}

\subsection{Conclusions}

Based on the aforementioned research, it can be concluded: 


\section{Marker DNA}

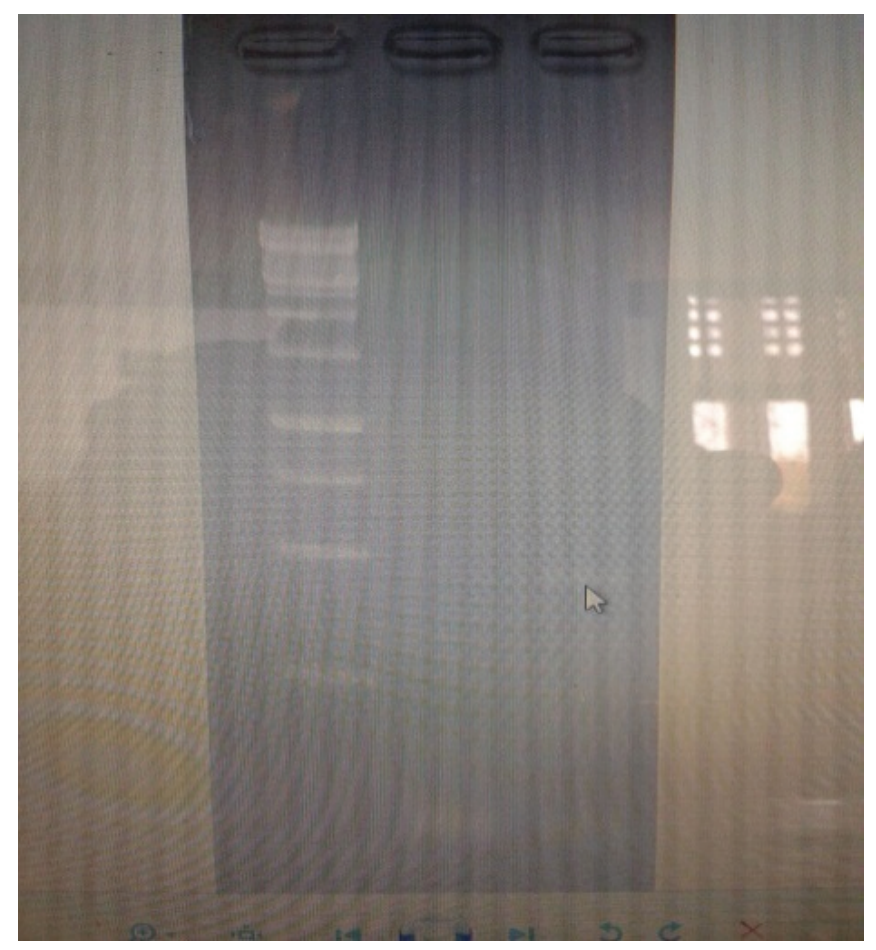

Figure 5: The results of agarose gel electrophoresis of DNA chromosomes of Aeromonas hydrophila.

1. The DNA result of the degradation protein of Aeromonas hydrophila isolate local East Java is $400 \mathrm{bp}$.

2. The result of DNA protein content from the degradation of Aeromonas hydrophila isolate local Java is $51.4 \mathrm{ng} / \mathrm{\mu l}$.

\subsection{Suggestion}

DNA that has been isolated can be used for the PCR test, by doing Sequencing Fragment Gen OMP A. Hydrophilic isolate East Java and continued with homology analysis and phylogenetic analysis. The result will be used as predictive determinant immunogenic.

\section{References}

[1] Abbas, KA, Lichtman, AH, Pober, JS. 2000. Cellular and molecular immunology 4th ed. WB Saunders Company A Harcourt Health Sciences Company Philadelphia London New York St Louis Sydney Toronto. 
[2] Adams J M and Cory S. 1998. The Bcl-2 Protein Family: Arbiters of Cell Survival. Science, 281:1322-1326

[3] Anonimus. 2001. Determinasi Bakteri Patogenik Penyebab Penyakit Ikan. Fakultas Pertanian. Universitas Gadjah Mada. Yogyakarta.

[4] Aoki, T. 1999. Motile Aeromonads (Aeromonashydrophila). In: Fish Disease Disorders. Viral, Bacterial, and Fungal Infection. Cab. Internation. Vol.3.

[5] Asha, A., DK. Nayak, KM. Shankar and CV. Mohan. 2004. Antigen expression in Biofilm cell of Aeromonas hydrophilla employed in oral vaccination of fish. Fish and Shellfish Immunology. 16:429-436

[6] Austin, B and A. Austin. 1999. "Vibrios as causal agents of zoonoses". Veterinary Microbiology. Vol.140:310-317

[7] Beesley, JE (eds), 1995. Immunocytochemistry. IRL Press New York.

[8] Chu, WH. and CP. Lu. 2008. In vivo fish models for visualizing Aeromonas hydrophilla invasion pathway using GFP as a biomarker. J. Aquaculture. 277:152-155

[9] Fahri, Muhammad. 2008. Bakteril Pathogen pada Budidaya Perikanan Vibrio alginolyticus. Program Pasca Sarjana Budidaya Perikanan Universitas Brawijaya

[10] Goldsby, AR, Kindt, TJ, and Osborne, BA, 2000. Kuby Immunology. WH Feeman and Company New York.

[11] Hayes, J. 2000. www.springtearmproject. Oregon state university, Net/aeromonas hydrophila.net/html

[12] Holm, JA. 1999. Disease Prevention and Control. Manual of Salmoning Farming. Blackwell Science. London.

[13] Holt, J.G, Krieg, N.R, Sneath, P.H.A, Staley, J.T, William, S.T. 1994. Bergey's Manual of Determinative Bacteriology. Nineth Edition.Williams \& Wilkins. A. Waverly Company, USA. P. 190-191; 254-255.

[14] Irianto, A. 2003. PatologilkanTeleostei. GadjahMada University Press. Yogyakarta.

[15] Jawetz, Meinick and Adelberg. Medical Microbiologi, 27th Edition. 2013. By McGrawHill Education.

[16] Suwarno. 2010. Deteksi Fragmen Gen Nukleoprotein Virus Rabies Isolat 200c Dari Anjing di Sumatra Barat Dengan Primer RN3 dan RN4. Veterinaria Medika.

[17] Taslihan, Arief, dkk. 2006. Layanan Jasa Diagnosis Patogen: Mikrobiologi, Histopatologi dan Biologi Molekuler dan Parasitologi untuk Mendukung Program Diseminasi Budidaya Udang (Balai Besar Pengembangan Budidaia Air Payau). Jepara: Departemen Kelautan dan Perikanan. 